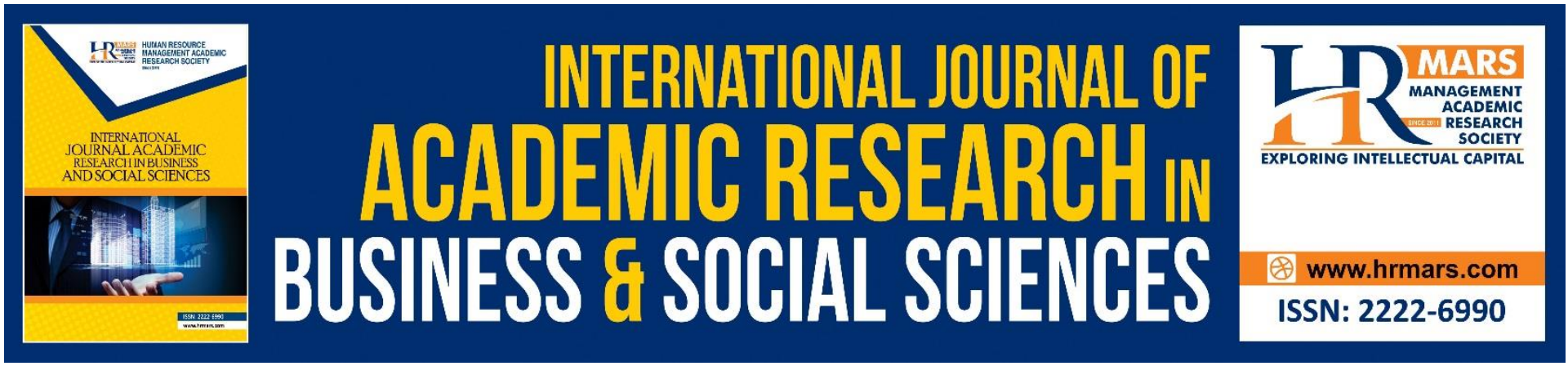

\title{
Delphi Technique: An Investigation Process of Standard Operating Procedure towards Apparel Small \& Medium Enterprise Sector in Malaysia
}

Rohana Zur

To Link this Article: http://dx.doi.org/10.6007/IJARBSS/v11-i9/10187

DOI:10.6007/IJARBSS/v11-i9/10187

Received: 03 July 2021, Revised: 07 August 2021, Accepted: 25 August 2021

Published Online: 12 September 2021

In-Text Citation: (Zur, 2021)

To Cite this Article: Zur, R. (2021). Delphi Technique: An Investigation Process of Standard Operating Procedure towards Apparel Small \& Medium Enterprise Sector in Malaysia. International Journal of Academic Research in Business and Social Sciences, 11(9), 1847-1885.

Copyright: @ 2021 The Author(s)

Published by Human Resource Management Academic Research Society (www.hrmars.com)

This article is published under the Creative Commons Attribution (CC BY 4.0) license. Anyone may reproduce, distribute, translate and create derivative works of this article (for both commercial and non-commercial purposes), subject to full attribution to the original publication and authors. The full terms of this license may be seen at: http://creativecommons.org/licences/by/4.0/legalcode

Vol. 11, No. 9, 2021, Pg. 1874 - 1885

Full Terms \& Conditions of access and use can be found at http://hrmars.com/index.php/pages/detail/publication-ethics 


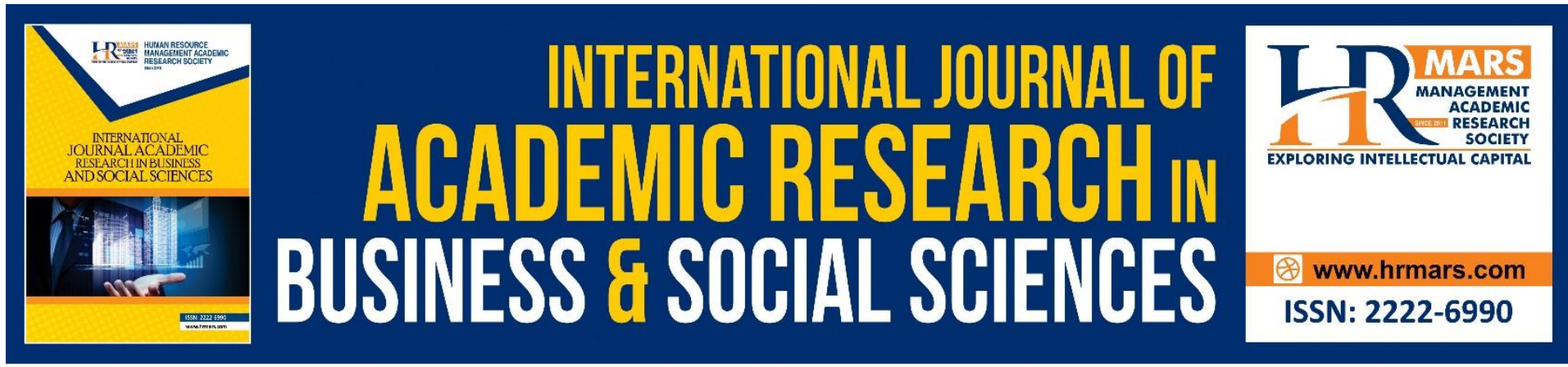

\title{
Delphi Technique: An Investigation Process of Standard Operating Procedure towards Apparel Small \& Medium Enterprise Sector in Malaysia
}

\author{
Rohana Zur \\ Malaysian Academy of SME \& Entrepreneurship Development (MASMED) \\ Universiti Teknologi MARA 40450 Shah Alam Selangor Malaysia \\ Email Corresponding Author: rohan316@uitm.edu.my
}

\begin{abstract}
This study aims to comprehend the process of Delphi study development using experts' consensus validation on the Standard Operating Procedure (SOP) framework of the SME apparel sector in Malaysia. The main objective of this research is to understand how the Delphi study can be used to ascertain the appropriate framework for SOP on the SME apparel sector. Due to the absence of any generic model as guidance, this research study is observed to be relevant to the needs of the industry. To obtain a coherent picture, an expert panel appointed in the Delphi study can assist in determining the suitable framework. All the data were acquired using the median, quartile, IQR, and QD analyses. Even though the findings obtained are only based on Delphi first round, the entire study findings are continued based on the analysis that will be obtained in subsequent Delphi rounds.
\end{abstract}

Keywords: Delphi Study, Standard Operating Procedure (SOP), Apparel SME in Malaysia.

\section{Introduction}

Standard Operating Procedure (SOP) is a specific term used to describe an operational system process, wherein, it explains every industry rule that involves a task, which gives the necessary result that is aligned with the required standard (Environmental Information Washington, 2007). SOP is substantially used in many industries that comprise manufacturing and service. The objective is to ensure that every process is performed consistently, every worker understands the routine task performed, and the production as well as product quality can be controlled and executed in the given time (Enterprise, 2015). SOP is not a new concept in the world of the apparel industry and is used extensively by most enterprises pertaining to the manufacturing industry (Shih et al., 2014). For the apparel industry, every party that works either in management or in operation will perform their duty as determined by the manufacturer through the SOP provided. There are various benefits pertaining to the usage of SOP in the apparel industry like:

a) Production of products that are of better quality and are more consistent.

b) Assists in avoiding delay problems in the production of a product. 
c) Helps in reducing communication problems among employees.

d) Increases employees' concentration in performing a given task.

e) It assists in training new employees regarding new procedures in line with industry standards.

f) Additionally, it can increase and maintain employees' safety in handling manufacturing machines.

Apart from these benefits, it must be noted that the language used in SOP should be comprehensible and must be stated in writing. It should have a title, code, logo and company name, areas involved, the responsibility of employees involved, approval and authorization date, procedure explanation, reference, and illustrated attachment if available (Barbosa et al., 2011). SOP in the apparel manufacturing industry must be displayed in close proximity to the workplace and must be stated in the worker's guidebook (Prasanta, 2013).

\section{Problem Statement}

The Small and Medium Enterprise (SME) apparel sector in Malaysia is a huge contributor to national economic development and is also acknowledged as the backbone of the industrial development program in the long run (Ping et al., 2010). Malaysian SME in the apparel sector under the category of textile, leather, and shoe has played an active role in establishing entrepreneurship and enhancing job opportunities for local residents (Subhan et al., 2013). The main activities of apparel SME in Malaysia include targeting the domestic market and fulfilling orders from big industry (Kufour, 2008; Wei, 2007). Nevertheless, apparel SME must act consciously to increase productivity and innovation and also work to maximize the export potential to the international market.

In order to ensure that the strategy is implemented effectively, SME in the apparel industry must produce more complex products, increase productivity, and encourage the development of more innovative products (Unit Perancang Ekonomi Malaysia, 2016). SME's factory organization needs to be more innovative in developing new products in the markets to compete with the existing competitors, to attract new customers, and to secure relationships with suppliers (Hidayah et al., 2015). According to the Economic Planning Unit (2016), in order to ensure the quality and production of innovative SME products and services, the government must encourage the SMEs to comply with the product-manufacturing standard. The 'Good Manufacturing Practice' will assist in developing new products in accordance with international standards.

Based on interviews with entrepreneurs belonging to apparel SMEs around Kuala Lumpur, Selangor, Johor, and Perak, it was found that the amount of apparel SMEs entrepreneurs that applied SOP in manufacturing activity was small. This was due to the lack of awareness regarding the importance of SOP application and the perception that SOP is a complex procedure. In addition, it was observed that there are certain SMEs that prefer to utilize the manual method, such as writing on paper and giving instructions, which have several weaknesses, such as human error, language problem, communication problem, and lack of understanding regarding the tasks and the instructions provided (Nizam et al., 2010; Noreen et al., 2012).

Consequently, the product development process requires a long time, increases the financial allocation, delays product delivery to the customer, and subsequently coerces the workers to work overtime in order to assure completion of urgent tasks (Ascloy et al., 2004). Such obstacles occur frequently and impact apparel SMEs entrepreneurs in inculcating brand 
reputation among customers and industrial practitioners. For this reason, the current study aims to provide efficient solutions in order to deal with the challenges in this field.

\section{Standard Operating Procedure (SOP) of Development Design for SME in Apparel Sector}

The SOP framework is developed based on two essential indicators: order activities involved and operational processes conducted. According to Collins and Glendinning (2005), order activities involved will ultimately affect operational processes conducted. Based on interviews obtained from the research population consisting of 343 apparel SMEs that agreed to cooperate, there are five order activities performed:

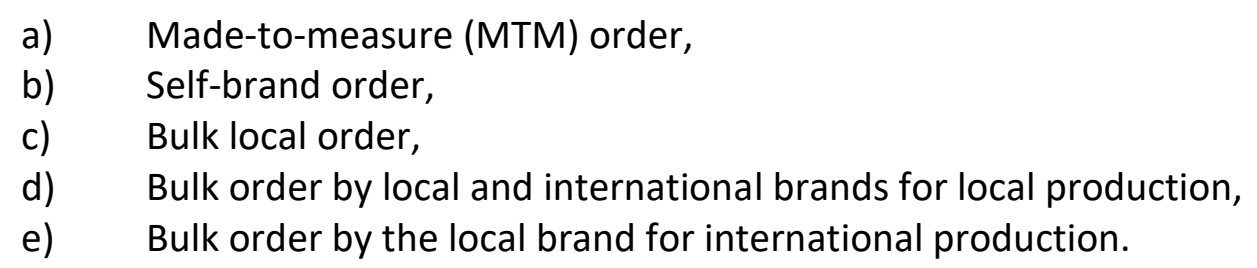

Production processes for order type number one to four (1-4), are usually done locally, while production type number five (5) is done abroad. Order type numbers one and two are mostly made by SMEs because the order is received in small quantities. Such orders frequently receive high demand from customers especially on festive seasons, social or formal functions, or on gatherings. However, bulk orders from number three to five (3-5) are found to be preferred by customers from local and international labels. Low sewing cost, fast sewing time, and ability to receive any order capacity have always made these services more popular and demanding among young customers who want creative and fresh designs (Hidayah et al., 2015).

Figure 1 shows a flow chart of an operational system that is designed at the preliminary stage based on five types of order activities. This flow chart has been classified into five parts, which follow the manufacturing standard based on the suitability of apparel SMEs' activity in Malaysia. Nonetheless, this study only focuses on framework findings from the Delphi technique. This study does not touch on the details of SOP development, though. 


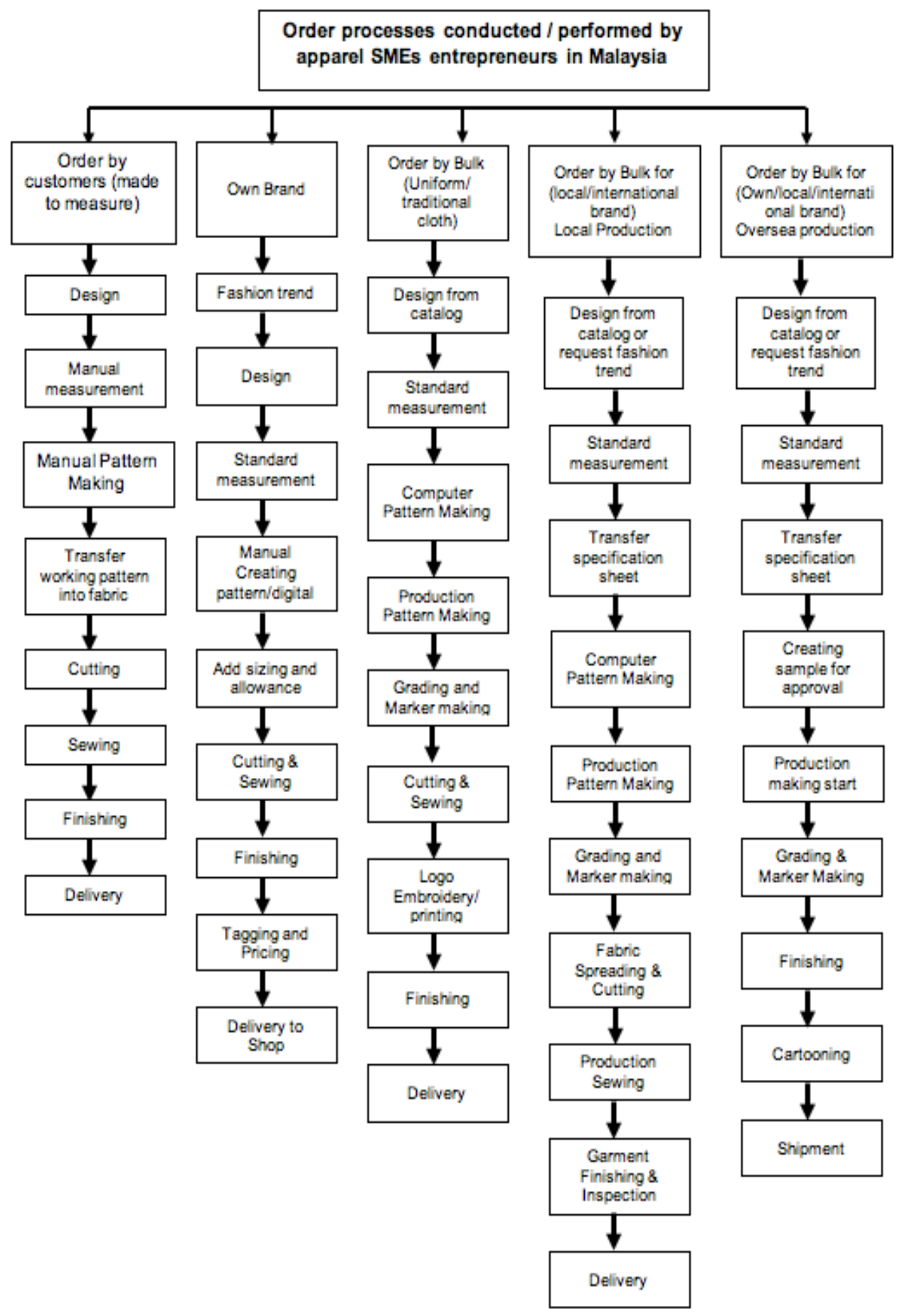

Figure 1. Flow chart an operational process based from the interviews 343 SMEs apparel in Malaysia.

\section{Research Methodology}

The analysis was performed using the Delphi technique to acquire experts' consensus viewpoints regarding the SOP design that is developed according to the suitability of SMEs' activities in Malaysia. Delphi technique includes both quantitative and qualitative methods that combine the views systematically in accomplishing an agreement or consensus (Yaakub \& Ismail, 2010). Delphi technique is suitable for this research because it can provide a clear 
decision in explaining the suitability of a method that could assist in the early development of this research framework. Although the usage of this technique is famous in pedagogy and health fields (Skulmoski \& Hartman, 2007), it has also been utilized broadly and extensively in apparel and textile industries, see Table 1:

Table 1

Previous Studies on Delphi Technique in Apparel \& Textile Industries.

\begin{tabular}{|c|c|c|c|c|}
\hline Authors & Title & Methodology & $\begin{array}{l}\text { Pane } \\
\text { I }\end{array}$ & $\begin{array}{l}\text { Roun } \\
\text { d }\end{array}$ \\
\hline $\begin{array}{l}\text { Huang \& Tan, } \\
2007\end{array}$ & $\begin{array}{l}\text { Product quality for apparel } \\
\text { industry in Taiwan }\end{array}$ & $\begin{array}{l}\text { Mean, median, mode, } \\
\text { standard deviation }\end{array}$ & 22 & 1 \\
\hline $\begin{array}{l}\text { Bigliardi et al., } \\
2011\end{array}$ & $\begin{array}{l}\text { Innovative cafeteria in Small \& } \\
\text { Medium Enterprises (SMEs) }\end{array}$ & $\begin{array}{l}\text { Descriptive analysis, } \\
\text { Discriminant analysis }\end{array}$ & 15 & 2 \\
\hline $\begin{array}{l}\text { Oxborrow, } \\
2015\end{array}$ & Apparel Supply Chain in Uk & $\begin{array}{l}\text { Mean \& standard } \\
\text { deviation } \\
\text { deviation was taken as a } \\
\text { proxy for the level of } \\
\text { consensus) }\end{array}$ & 24 & 2 \\
\hline Ning, 2006 & $\begin{array}{l}\text { Apparel \& textile supply Chain } \\
\text { in Hong Kong }\end{array}$ & $\begin{array}{l}\text { Coefficient of variation } \\
\text { was employed to judge } \\
\text { whether they have } \\
\text { consensus to certain } \\
\text { extent), Cronbach's, Fuzzy } \\
\text { measure }\end{array}$ & 10 & 3 \\
\hline $\begin{array}{l}\text { Venkatesh \& } \\
\text { Paluri, } 2016\end{array}$ & $\begin{array}{l}\text { India's SME apparel } \\
\text { manufacturing }\end{array}$ & $\begin{array}{l}\text { Interpretive structural } \\
\text { modelling analysis }\end{array}$ & 8 & 1 \\
\hline Lee et al., 2002 & $\begin{array}{l}\text { Apparel \& } \begin{array}{r}\text { Textile } \\
\text { manufacturing } \\
\text { characterisation and needs } \\
\text { assessment }\end{array}\end{array}$ & $\begin{array}{l}\text { Descriptive Statistics } \\
\text { (mean) }\end{array}$ & 22 & 2 \\
\hline $\begin{array}{lr}\text { Gupta } & \& \\
\text { Dasgupta, } 2015\end{array}$ & $\begin{array}{l}\text { Apparel transportation lead } \\
\text { time }\end{array}$ & $\begin{array}{l}\text { Principle component } \\
\text { analysis multiple } \\
\text { regression analysis }\end{array}$ & 16 & 2 \\
\hline
\end{tabular}

To ensure the implementation of the Delphi technique, several things must be emphasized like experts as panels, panel size, methodology selection, preliminary research questions, number of rounds, and consensus achievement setting (Yaakub \& Ismail, 2010).

\section{Preliminary Research Questions}

Questions built in the Delphi technique could be set in an open form and broad scope. However, the questions that focus on a limited scope could also be applied in this Delphi research method (Adler \& Ziglio, 1996). Such questions only require a short, thorough, and simple answer to limit the discussion. Thus, the selection of using a limited scope, to measure Standard Operating Procedure (SOP) design for apparel SMEs in Malaysia, is appropriate for this study. Likert scale was used to rate 1 (strongly disagree), 2 (disagree), 3 (not sure), 4 (agree), and 5 (strongly agree). For each question, an item was displayed on one side, a Likert scale as well as a space to state view, comment or retrieve suggestions from experts. 


\section{Selection of Expert Panel}

The selection of expert's panel in the Delphi study is a major issue to ensure the smoothness of the research process and determine the decisions pertaining to a research finding (Sani, 2016; Yousuf, 2007). The qualified experts selected met all the below mentioned criteria (Woudenberg, 1991):

a) They have broad experiences and knowledge in the domain of research conducted.

b) They are fully committed to every Delphi round conducted.

c) They are able to provide views and suggestions that are related to the research field.

Generally, the size of the members involved as experts' groups is different, depending on the research sample factor required. There are two sample sizes, which represent the panel group for the Delphi technique: homogeneous group (a group of experts that represent similar expertise) and heterogeneous group (a group of experts that have expertise in the topic but are from a different social or professional group) (Somerville, 2008).

If it involves international research, a heterogeneous approach of experts' group will be considered and the number of experts within the group must exceed 100 people (Dalkey, 1969). Meanwhile, if the research sample is homogeneous a small number of experts, between 10 and 15, is sufficient for the group (Yaakub \& Ismail, 2010; Ziglio, 1996). Nevertheless, several literature studies state that the number of experts between 6 and 12 is optimal for combining systematic views from a homogeneous group of experts (Hogarth, 1978; Mitchell, 1991). Additionally, it is observed that a smaller number of experts have a better performance than a larger number of experts as it ensures an ideal and more secure decision (Yaakub \& Ismail, 2010).

For this study, eight experts have been identified as experts' panel from the homogeneous group, based on expert's selection criteria (Hogarth, 1978; Mitchell, 1991). The experts must have enormous experiences and knowledge in the Malaysian fashion and SME industry. For this reason, the selected group of experts required for the current study consists of industrial practitioners and academics, who are involved comprehensively in the apparel industry in Malaysia. The experts agree to participate in a number of rounds in Delphi until the consensus is achieved. Experts panel were selected based on their willingness, ability, experience, and knowledge concerning asserting views regarding the research (French et al., 2002). Apart from that, experts' opinions from SME Corp., which handles apparel SMEs in Malaysia, were also sought in this study. The involvement of expert groups who have different perspectives will provide a better consensus based on their respective views and expertise (Okoli \& Pawlowski, 2004).

\section{Data Analysis Setting}

According to Yaakub \& Ismail, (2010), the consensus level within the research study can be determined using a precise scale. Statistical analysis methods such as median, quartile, IQR, and QD are used to measure agreement or consensus level among expert panels. Median is used to measure a more specific tendency than the mean (Mahmod \& Dahalin, 2015).

However, to obtain a variety of results, Inter-Quartile Range (IQR) usage is considered (Mahmod \& Dahalin, 2015). Items in this study have been divided into three levels according to the agreement achieved: low, moderate, and high. Median is the center point of a data set and IQR is the difference between the third quartile and the first quartile. Meanwhile, QD is half of IQR. There are three levels of $Q D$ : high ( $Q D=0.0-0.5)$, moderate $(Q D=0.51-1.00$ ) and 
low $(Q D=>1.00)$. A high QD level signifies a high level of agreement among respondents, while a moderate QD agreement indicates the item is in a moderate agreement level. Whereas a low QD level depicts a low agreement level regarding the item and needs to be reviewed. Thus, only high and moderate consensus levels will be considered in this study, and a low consensus level will be considered in the subsequent round. Consensus levels are explained in table 2 below:

Table 2

Consensus Level Obtained from Kasem (1979) and Narongsakhet (2003) research studies.

\begin{tabular}{|c|c|c|c|}
\hline $\begin{array}{l}\text { Quartile Deviation } \\
\text { (QD) }\end{array}$ & Consensus & Median (M) & Significance Level \\
\hline$Q D<0.5$ & High & $M>4$ & High \\
\hline $0.5<Q D<1.0$ & Moderate & $M<3.5$ & Low \\
\hline $\mathrm{QD}>1.0$ & Low or No Consensus & & \\
\hline
\end{tabular}

\section{Delphi Round}

For this study, 42 Delphi questions are prepared that represent apparel SME's order activities and its integration with SOP practices. SOP instrument questions need to be prioritized to give an understanding of the uniformity of SOP with the types of orders performed by Malaysian apparel SME companies. Findings from these questions will assist in ascertaining the main procedure of apparel manufacturing processes in Malaysian SME. The questions for Delphi first round have been provided to all panels involved through e-mail and direct delivery to the panel involved. The panel was given a month to state the agreed scale and suggestion or opinion for enhancement. The researcher had difficulty in collecting all the answers given, especially from the expert panel that was involved with the industrial practitioner; however, the researcher was able to collect all the questions of Delphi first round after the time given. All the questions were analyzed by using the median, interquartile range (IQR), and quartile deviation (QD) to determine the consensus.

\section{Results and Conclusion}

The analysis showed that all five types of order indicators achieved high and moderate levels of consensus, between QD (0-0.5) and QD (0.51-1.00). The results demonstrated no process was eliminated from the framework, although there were several suggestions from the panel for enhancement on all the manufacturing processes. Nonetheless, items for question Q12, B9, and B13, which were on a moderate level of consensus, did not change because there was no enhancement suggestion from the panel. Items that achieved a high agreement level will be retained for Delphi first round, while items that achieved the lowest consensus level will be reviewed for Delphi's second round. Enhancements have been made after analyzing according to consensus conducted. Various opinions and suggestions were provided by the expert panel in understanding the real meaning of SOP usage in the SME apparel sector in Malaysia. The results from Delphi's first round are depicted in Figure 2. 
INTERNATIONAL JOURNAL OF ACADEMIC RESEARCH IN BUSINESS AND SOCIAL SCIENCES Vol. 11, No. 9, 2021, E-ISSN: 2222-6990 @ 2021 HRMARS

\begin{tabular}{|c|c|c|c|c|c|c|c|c|}
\hline \multicolumn{2}{|c|}{ Process } & \multicolumn{2}{|c|}{$\begin{array}{c}\text { SOP1 } \\
\text { Order by customer } \\
\text { (mado-tomeasure) }\end{array}$} & \multicolumn{2}{|c|}{$\begin{array}{c}\text { SOP2 } \\
\text { Order for Own } \\
\text { (Brandidesign) }\end{array}$} & $\begin{array}{c}\text { SOP } 3 \\
\text { Order by bukk } \\
\text { (Unform) } \\
\end{array}$ & $\begin{array}{c}\text { SOP4 } \\
\text { Order by buk (brand) } \\
\text { (Producton Loca) }\end{array}$ & $\begin{array}{c}\mathrm{SOP} 5 \\
\text { Order by buk (brand) } \\
\text { (Production Oversea) } \\
\end{array}$ \\
\hline \multirow{7}{*}{$\begin{array}{l}\text { Pre. } \\
\text { Production } \\
\text { process }\end{array}$} & \multirow{3}{*}{$\begin{array}{c}\text { (PI) } \\
\text { Ordering and } \\
\text { measurement }\end{array}$} & $\begin{array}{l}\text { Personal } \\
\text { Customer order }\end{array}$ & $\begin{array}{l}\text { Onine retal Pre- } \\
\text { Order }\end{array}$ & \multicolumn{2}{|c|}{$\begin{array}{c}\text { Own design order and oniline retal pre- } \\
\text { arder } \\
\text { (loca brand) }\end{array}$} & Cusiomer order from the calialog & $\begin{array}{l}\text { Cusiomer order from } \\
\text { localloversesea brand }\end{array}$ & $\begin{array}{l}\text { Cusiomer order from local } \\
\text { loversea brand }\end{array}$ \\
\hline & & $\begin{array}{l}\text { Cusiomer own } \\
\text { desiggn }\end{array}$ & $\begin{array}{l}\text { From the Online } \\
\text { Catalog }\end{array}$ & \multicolumn{2}{|c|}{$\begin{array}{l}\text { Fashion Trends: Lentify the quantily, } \\
\text { matera, color, outtng, act }\end{array}$} & Caitilog: Into design matters & $\begin{array}{l}\text { Into ordering indude design } \\
\text { matters }\end{array}$ & $\begin{array}{l}\text { Info ordering indude design } \\
\text { matters }\end{array}$ \\
\hline & & $\begin{array}{l}\text { Manual } \\
\text { measurement }\end{array}$ & $\begin{array}{l}\text { Standard format } \\
\text { Measurement }\end{array}$ & \multicolumn{2}{|c|}{$\begin{array}{l}\text { Standard format Measurement of } \\
\text { Custom measurement }\end{array}$} & Standard format set Measurement & Standard format Nessurement & Standaro fomat Neasurement \\
\hline & \multirow{4}{*}{$\begin{array}{l}\text { (P2) } \\
\text { Idega } \\
\text { Develooment } \\
\text { (Confrming } \\
\text { design, } \\
\text { material, } \\
\text { shape, } \\
\text { accessoress, } \\
\text { color, act) }\end{array}$} & \multirow{2}{*}{\multicolumn{2}{|c|}{ Drawing: Manual or Computerize }} & \multirow{2}{*}{\multicolumn{2}{|c|}{$\begin{array}{c}\text { Manual Sketch or Computenze } \\
\text { Drawing/printrng (CAD) } \\
\text { Manual embroddery }\end{array}$}} & \multirow{2}{*}{$\begin{array}{c}\text { Computerize Drawing printing } \\
\text { embroidery } \\
\text { (CAD) }\end{array}$} & \multirow{2}{*}{$\begin{array}{l}\text { Computerize Drawing printingl } \\
\text { embroidery } \\
\text { (CAD) }\end{array}$} & Spectication Sheed Preparation \\
\hline & & & & & & & & $\begin{array}{l}\text { Computerize Drawing / priningl } \\
\text { embrodery } \\
\text { (CAD) }\end{array}$ \\
\hline & & \multicolumn{2}{|c|}{$\begin{array}{l}\text { Order calculation } \\
\text { and confim by custiomer }\end{array}$} & \multicolumn{2}{|c|}{$\begin{array}{l}\text { Order calouation } \\
\text { and meeting }\end{array}$} & $\begin{array}{c}\text { Standard order calculation and } \\
\text { confirm by customer }\end{array}$ & $\begin{array}{l}\text { Standard calculation and group } \\
\text { meeting }\end{array}$ & $\begin{array}{l}\text { Expenditure Calculation and } \\
\text { group meting }\end{array}$ \\
\hline & & \multicolumn{2}{|c|}{ Place Order } & \multicolumn{2}{|c|}{ Place Order } & $\begin{array}{c}\text { Place Order } \\
\text { Spectication Sheed }\end{array}$ & $\begin{array}{c}\text { Place Order } \\
\text { Specificaton Sheet }\end{array}$ & $\begin{array}{c}\text { Place Orderer } \\
\text { (oversea production) }\end{array}$ \\
\hline \multirow{10}{*}{$\begin{array}{l}\text { Production } \\
\text { processs }\end{array}$} & \multirow{5}{*}{$\begin{array}{c}\text { (P3) } \\
\text { Nodel } \\
\text { Development }\end{array}$} & \multirow{2}{*}{\multicolumn{2}{|c|}{ Final dessign with material selection }} & \multirow[t]{2}{*}{ Creation Sampling } & & $\begin{array}{l}\text { Sampling Creation and confirm the } \\
\text { samping }\end{array}$ & $\begin{array}{l}\text { Sampling Creation and confrm } \\
\text { the sanpling }\end{array}$ & \multirow[t]{2}{*}{$\begin{array}{l}\text { Fit Sample } \\
\text { (oversaa production) }\end{array}$} \\
\hline & & & & & & $\begin{array}{l}\text { Producton Standard pattem } \\
\text { making (20 CAD) }\end{array}$ & $\begin{array}{l}\text { Producton Standard pattern } \\
\text { making (20 CAD) }\end{array}$ & \\
\hline & & \multicolumn{2}{|c|}{ Create the pattern (by manually) } & $\begin{array}{l}\text { Manual Creating } \\
\text { Pattern }\end{array}$ & & $\begin{array}{l}\text { Creating range of siza by Grading } \\
\text { (20 CAM) }\end{array}$ & $\begin{array}{l}\text { Creating range of size by } \\
\text { Grading (20 CAM) }\end{array}$ & $\begin{array}{l}\text { Than confrmation sample } \\
\text { (oversea production) }\end{array}$ \\
\hline & & \multicolumn{2}{|c|}{ Add Seam allowances } & $\begin{array}{l}\text { Manual Correcilon and } \\
\text { cheoking siza sat of } \\
\text { pattern }\end{array}$ & $\begin{array}{l}\text { Outsourcing } \\
\text { production }\end{array}$ & $\begin{array}{l}\text { Algn all size pattern Marker } \\
\text { makng (20 CAM) }\end{array}$ & $\begin{array}{l}\text { Algn all size pattern Marker } \\
\text { makng (20CAM) }\end{array}$ & \multirow{7}{*}{$\begin{array}{l}\text { Producton siat (oversea } \\
\text { production) }\end{array}$} \\
\hline & & \multicolumn{2}{|c|}{$\begin{array}{l}\text { Finalist a the pattern before cuting } \\
\text { procosss }\end{array}$} & Add Seam allowances & & $\begin{array}{l}\text { Confirmation al the pattern (20) } \\
\text { CAY) }\end{array}$ & $\begin{array}{l}\text { Confirmation al the pattem (20) } \\
\text { CAY) }\end{array}$ & \\
\hline & \multirow{5}{*}{$\begin{array}{c}\text { (PA) } \\
\text { Production } \\
\text { Development }\end{array}$} & \multicolumn{2}{|c|}{ Manual Fabrc Spreading } & $\begin{array}{l}\text { Manual Fabric } \\
\text { Soceading }\end{array}$ & & $\begin{array}{l}\text { Fabric Spreading } \\
\text { Manualautomatic (30 CAM) }\end{array}$ & $\begin{array}{l}\text { Fabric Spreading } \\
\text { Manual/auiomatic (30 CAMI) }\end{array}$ & \\
\hline & & \multicolumn{2}{|l|}{ Manual cutting } & Menual cuting & & Computerized outtng (30 CAM) & Computerzed autting (30 CAM) & \\
\hline & & \multicolumn{2}{|c|}{ Connection of group sewing } & $\begin{array}{l}\text { Connection of group } \\
\text { sewing }\end{array}$ & $\begin{array}{c}\text { a } \\
\text { Outsourcing }\end{array}$ & $\begin{array}{l}\text { Bundingh Hanger all the cutting } \\
\text { fabric }\end{array}$ & $\begin{array}{l}\text { Bundingh Hanger al the cutting } \\
\text { fabric }\end{array}$ & \\
\hline & & \multicolumn{2}{|c|}{ Sewing Manual Enbroddery } & $\begin{array}{l}\text { Sewing Manual } \\
\text { Embrodery }\end{array}$ & production & Connecion of group sewing & Connection of group sewing & \\
\hline & & \multicolumn{2}{|l|}{ OC gasment } & QC garment & & $\begin{array}{l}\text { Sewing Computerize } \\
\text { Embroddery/Printing (30 CAM) }\end{array}$ & $\begin{array}{l}\text { Sewing Computerize } \\
\text { Embrodery/Pinting (30 CAM) }\end{array}$ & \\
\hline \multirow{4}{*}{$\begin{array}{l}\text { Post } \\
\text { Production } \\
\text { process }\end{array}$} & \multirow{4}{*}{$\begin{array}{c}(P G) \\
\text { Final } \\
\text { Production }\end{array}$} & Finishing & & Tragging & $\begin{array}{l}\text { Garment } \\
\text { Inspection } \\
\text { (visit) }\end{array}$ & OCOA Gamentinspection & Garment hspection & $\begin{array}{l}\text { OC OAA Garment Inspection } \\
\text { (visit) }\end{array}$ \\
\hline & & Dellivery to cusito & & Finishing & Finishing & Finishing \& Packaging & Finishing \& Packaging & Finishing \& cartooning \\
\hline & & & & Delivery to shop & Cartooning & Dellvery and Distoution & Dellvery and Distroution & Delivery and Distibution \\
\hline & & & & & Shipment & Delluery & Deliven & Shoment \\
\hline
\end{tabular}

Figure 2. The generic model constructed after analyzing Delphi first round

The findings show Standard Operating Procedures (SOPs) still need further scrutiny. According to experts involved in this Delphi method, the SOP items approach needs to be validated so the procedures stated are aligned with the needs of apparel SME in Malaysia. Although the Delphi method requires a long time to obtain agreements or consensus among experts, this method is viewed as one of the best methods in identifying SOP development for SMEs in the 
apparel sector. Even though research findings are based only on Delphi first round, it clearly shows that the importance of SOP usage among SMEs entrepreneurs in the apparel sector in Malaysia needs to be standardized. Perhaps, consensus level decisions might change if there is a low agreement level on Delphi's second round and the subsequent rounds. However, if this happens, the researcher suggests the use of the Delphi Fuzzy Method or case study that is capable of acquiring data accurately with only a single round based on experts' consensus. This matter needs to be scrutinized and evaluated based on previous research studies to acquire certainty on its usage in the apparel industry.

\section{Acknowledgement}

The authors would like to acknowledge University Technology MARA (UiTM) for their support through this research, the Malaysian Academy of SME \& Entrepreneurship Development (MASMED), and the Faculty of Art \& Design for supporting this research with invaluable information. This research received no specific grant from any funding agency in the public, commercial, or not-for profit sectors. Furthermore, the researcher would like to thank all experts panel for their cooperation and valuable input.

\section{References}

Adler, M., \& Ziglio, E. (1996). Gazing into the oracle. Jessica Kingsley Publishers: Bristol, PA. Ascloy, N., Haan, E. De, \& Dent, K. (2004). Critical issues for the garment industry. Amsterdam.

Barbosa, C. M., Mauro, M. F. Z., Cristovao, S. A. B., \& Mangione E, J. A. (2011). The importance of standard operating procedures (SOPs) for clinical research centres. Rev Assoc Med Bras, 57(2), 132-133.

Bigliardi, B., Colacino, P., \& Dormio, A. I. (2011). Innovative Characteristics of Small and Medium Enterprises. Journal of Technology Management \& Innovation, 6(2), 84-93.

Collins, P., \& Glendinning, S. (2005). Production Planning in the Clothing Industry: Failing to Plan is Planning to Fail. Control, iomnet.org.uk. UK.

Dalkey, N. (1969). The Delphi Method: An Experimental Study of Group Opinion. The RAND Corporation. Retrieved from http://linkinghub.elsevier.com/retrieve/pii/S001632876980025X

Ekonomi, U. P. (2016). Memperkasakan pertumbuhan ekonomi untuk peningkatan kemakmuran. Rancangan Malaysia Kesebelas. Putrajaya.

Enterprise, B. S. B. (2015). What is a Standard Operating Procedure (SOP)? Canada.

Environmental Information Washington, E. (2007). Guidance for Preparing Standard Operating Procedures (SOPS): EPA QA/G-6. Washington.

French, P., Ho, Y. Y., \& Lee, L. S. (2002). A Delphi survey of evidence-based nursing priorities in Hong Kong. Journal of Nursing Management, 10(5), 265-273. http://doi.org/10.1046/j.1365-2834.2002.00314.x

Gupta, A., \& Dasgupta, P. (2015). Inland Transportation and Lead Time of Apparel Exports. Proceedings of the Hamburg International Conference of Logistics (HICL)-20, (August), 451-477.

Hidayah, N., Baba, M. D., \& Mohd Fitri, M. (2015). Halatuju dan permasalahan pelaksanaan proses pra pembangunan produk baharu: Perspektif PKS Malaysia Jurnal Teknologi. Journal Teknologi, (November). http://doi.org/10.11113/jt.v77.6060

Hogarth, R. M. (1978). A note on aggregating opinions. Organizational Behavior and Human Performance, 21(1), 40-46. http://doi.org/10.1016/0030-5073(78)90037-5 
Huang, Y. Y., \& Tan, B. (2007). Applications of quality function deployment to apparel design in Taiwan. Journal of Fashion Marketing and Management. http://doi.org/10.1108/13612020710751392

Narongraksakhet, I. (2003). Developing Local-based Curriculum Guidelines for Islamic Private Schools in Southern Thailand. (Tesis ljazah Doktor Falsafah yang tidak diterbitkan). Universiti of Malaya, Kuala Lumpur.

Kasem, B. 1979. The future of teacher education in Thailand: A Delphi application. Doctoral dissertation, University of Alabama, Alabama.

Kufuor, A. a. (2008). Employment Generation and Small Medium Enterprise (SME) Development - the Garment and Textile Manufacturing Industry in Ghana. Paper submitted at The International Forum on Sustainable Private Sector Development, Growing Inclusive Markets Forum in Halifax, Nova Scotia, Canada, June 19th - 21st 2008, 1-11.

Lee, Y.-A., Sontag, M. S., \& Slocum, A. C. (2002). Michigan Apparel and Textile Manufacturing Industry: Characterization and Needs Assessment. In Article Designation: Refereed JTATM (Vol. 2, Issue 3). http://www.sourcingmall.com

Mahmod, M., \& Md. Dahalin, Z. (2015). Open source software : A Gendered Technology? The Third Information Systems International Conference.

Mitchell, V. W. (1991). The delphi technique: an exposition and application. Technology Analysis \& Strategic Management, 3(4), 333-358. http://doi.org/10.1080/09537329108524065

Mohd Nizam, A. R., Rosmaizura, M. Z., Suriani, A. R., \& Zulkifli, M. N. (2010). Peningkatan prestasi proses melalui peralatan kualiti berstatistik. Journal of Quality Measurement and Analysis, 6(1), 1-15.

Ning, C. (2006). Supply chain performance measurement in textile and apparel industries.

Noreen, A. R., Nor Shahbiha, R., Nur Adilah, A. K., Nurshaida, A. H., \& Thangaeswari, R. (2012). Mengkaji keberkesanan komunikasi pengusaha PKS Pulau Pinang.pdf. Seberang Perai.

Okoli, C., \& Pawlowski, S. D. (2004). The Delphi method as a research tool : an example, design considerations and applications. Information \& Management, 42(1), 15-29. http://doi.org/10.1016/j.im.2003.11.002

Oxborrow, L. (2015). Future Scenarios in Uk Apparel Supply Chains: A Disaggregative Delphi Study.

Ping, H. H., Lee, T. P., Ahmed, P. (2010). Malaysian Women Entrepreneurs: The Neglected Enterprising Selves, 2005, 0-14.

Prasanta, S. (2013). Standard Operating Procedures: A process Management Tool for the Garment factories.

Yaakub, S. \& Ismail, Z. (2010). Pembangunan Instrumen Literasi Alam Sektar Pelajar Sekolah Menengah menggunakan Teknik Delphi. Malaysian Education Dean's Council (MEDC) Journal, 10, 79-89. http://doi.org/10.1017/СBO9781107415324.004

Sani, M. (2016). Pembinaan Kerangka Standard Kompetensi Literasi Ict Kebangsaan: Kajian Delphi. International Seminar on Generating Knowledge Through Research, 1(October), 25-27.

Shih, W. Y. C., Agrafiotes, K., \& Sinha, P. (2014). New product development by a textile and apparel manufacturer: a case study from Taiwan. The Journal of The Textile Institute, 105(9), 905-919. http://doi.org/10.1080/00405000.2013.862914 
Skulmoski, G. J., \& Hartman, F. T. (2007). The Delphi Method for Graduate Research. Journal of Information Technology Education, 6(1), 1-21. http://doi.org/10.1.1.151.8144

Somerville, J. A. (2008). Effective Use of the Delphi Process in Research: Its Characteristics, Strengths and Limitations 1. Oregon State University, (2007), 1-11.

Subhan, Q. A., Mehmood, M. R., \& Sattar, A. (2013). Innovation in Small and Medium Enterprises (SMEs) and its impact on Economic Development in Pakistan. Proceedings of the 6th International Business and Social Sciences Research Conference, (92), 1-18.

Venkatesh, V., \& Paluri, R. (2016). Sustenance of Indian apparel manufacturing industry in post MFA period-a strategic analysis. Int. J. Process, (April). http://doi.org/10.1504/IJPMB.2016.077632

Wei, S. L. (2007). Malaysian Textile \& Apparel Industry. Socio-Economic \& Environmental Research Institute, pp. 1-11.

Woudenberg, F. (1991). An evaluation of Delphi. Technological Forecasting and Social Change, 40(2), 131-150. http://doi.org/10.1016/0040-1625(91)90002-W

Yousuf, M. I. (2007). Using experts' opinions through Delphi technique. Practical Assessment, Research \& Evaluation, 12(4), Available online: http://pareonline.net/getvn.asp? http://doi.org/May 2007

Ziglio, E. (1996). The Delphi Method and its Contribution to Decision-making. In Gazing Into the Oracle: The Delphi Method and Its Application to Social Policy and Public Health (p. 252). 